\title{
FAKTOR-FAKTOR YANG MEMPENGARUHI PERILAKU SEKSUAL PRANIKAH PADA REMAJA SMP DAN SMA DI WILAYAH EKS- KOTA ADMINISTRATIP CILACAP
}

\author{
Mariah Ulfah \\ Program Studi Kebidanan, Fakultas Kesehatan, Universitas Harapan Bangsa Purwokerto, Jawa Tengah \\ Email : maydaanzili@gmail.com
}

\begin{abstract}
ABSTRAK
Latar Belakang: Sebuah penelitian di salah satu SMA X di Kabupaten cilacap ditemukan bahwa 3,3 persen dari 123 siswa kelas XI sudah melakukan hubungan seksual, dan dari informasi guru BK (bimbingan konseling) yang ditemui oleh peneliti menyebutkan bahwa perilaku tersebut sudah dilakukan sejak siswa duduk di bangku SMP.

Tujuan: Mengetahui faktor-faktor yang mempengaruhi perilaku seksual pranikah pada remaja SMP dan SMA di wilayah eks-kota administratip Cilacap

Metode: Jenis penelitian ini merupakan penelitian analitik observasional dengan desain crossectional. Penelitian dilakukan di 5 sekolah SMP dan 12 sekolah SMA di kabupaten Cilacap pada tahun 2013. Populasi penelitian adalah seluruh remaja (putra-putri) yang duduk di bangku SMP dan SMA dengan jumlah sampel sebanyak 596 orang yang dipilih secara Systematic Random Sampling. Variabel-variabel penelitian diukur dengan menggunkan angket. Analisa data menggunakan analisis jalur/path analysis dengn program PLS.

Hasil: Tidak ada pengaruh langsung karaktersitik remaja, sikap masyarakat, orang tua, teman dan sikap terhadap seks terhadap perilaku seksual pranikah $(\mathrm{t}<1.96)$. Ada pengaruh langsung akses media, peran guru, persepsi, pengetahuan dan nilai virginitas terhadap perilaku seksual pranikah pada remaja putri SMP SMA di Kabupaten Cillacap ( $t>1.96$; $R$ square 0.336 ).

Kesimpulan: $36.6 \%$ Perilaku seksual pranikah pada remaja SMP dan SMA di Kabupaten Cilacap dipengaruhi oleh akses media, peran guru, persepsi, pengetahuan dan nilai virginitas.
\end{abstract}

Kata Kunci: Remaja, Perilaku seksual pranikah, SMP, SMA

\section{PENDAHULUAN}

Masa remaja adalah masa peralihan dari masa anak ke masa dewasa, meliputi semua perkembangannya yang dialami sebagai persiapan memasuki masa dewasa, yang meliputi berbagai perubahan, baik dalam hal fisik, kognitif, psikologis, spiritual, maupun sosial dan ekonomi (Berck, 2012). Perubahan fisik merupakan gejala primer dalam pertumbuhan remaja dan perubahan psikologis muncul antara lain sebagai akibat dari perubahan-perubahan fisik tersebut. Salah satu contoh perubahan fisik yang terjadi adalah semakin matangnya organ-organ reproduksi. Kematangan biologis menyebabkan remaja memiliki dorongan-dorongan seksual. Akibatnya, timbul minat pada hal-hal yang berhubungan dengan masalah seksual dan juga ketertarikan terhadap lawan jenis. Pergaulan remaja perempuan dan remaja laki-laki menjadi sangat bebas, bahkan sampai pada tahap mengkhawatirkan. Seks bebas dan aktivitas seksual pranikah serta maraknya kriminalitas aborsi. Hal tersebut disebabkan karena perubahan zaman akibat masuknya budaya barat ke dalam budaya Indonesia (Fanchaurt, 2010)

Survei yang dilakukan oleh SKRRI (Survei Kesehatan Reproduksi Remaja Indonesia) 2017 menyebutkan bahwa prosentase wanita dan pria usia 15-24 tahun yang belum kawin dan pernah melakukan hubungan seksual pranikah yaitu pada wanita 
M Ulfah | Faktor-faktor yang Mempengaruhi Perilaku Seksual Pranikah pada Remaja SMP dan SMA di Wilayah Eks-Kota Administratip Cilacap

usia $15-19$ tahun sebanyak $0.9 \%$, wanita usia 20-24 tahun 2,6\%, sedangkan pada laki-laki usia 15-19 tahun sebanyak $3,6 \%$ dan usia 20-24 tahun sebanyak 14,0\%. (Tim SDKI, 2018)

Penelitian lain di salah satu SMA X di Kabupaten cilacap ditemukan bahwa 3,3 persen dari 123 siswa kelas XI sudah melakukan hubungan seksual, dan dari informasi guru BK (bimbingan konseling) yang ditemui oleh peneliti menyebutkan bahwa perilaku tersebut sudah dilakukan sejak siswa duduk di bangku SMP. Penelitian yang dilakukan di Kecamatan Cilacap Selatan pada remaja rentang usia 12-17 tahun jumlah sampel 58 orang remaja SMP 30, SMA 28 orang ditanyakan bila melakukan hubungan seksual pranikah dengan pacar, responden menyatakan 58,6 persen menolak, namun 41,4 persen remaja menyetujui pernyataan tersebut (Wisesa, 2011 dan Dhion, 2011). Berdasarkan bahasan tersebut, peneliti merasa penting untuk mengetahui bagaimana melakukan upaya preventif dengan melihat nilai virginitas dalam upaya mencegah perilaku seksual pranikah menurut perpektif remaja SMP dan setingkat SMA di Wilayah Eks-Kotip Cilacap.

\section{METODE}

Jenis penelitian ini merupakan penelitian analitik observasional dengan desain crossectional (Notoatmodjo, 2010).. Penelitian dilakukan pada tahun 2013 di 5 (lima) sekolah SMP dan 12 (duabelas) sekolah SMA di eks-kota administratip Cilacap. Populasi penelitian adalah seluruh remaja (putra-putri) yang duduk di bangku SMP dan SMA dengan jumlah sampel sebanyak 596 orang yang dipilih secara Systematic Random Sampling (Suharsimi, A. 2010; Sugiyono, 2010)

Variabel dalam penelitian adalah karakteristik remaja, akses media (seksualitas dan pornografi), sikap (individu terhadap seks, masyarakat, orang tua dan teman), persepsi, pengetahua dan nilai virginitas. Instumen penelitian menggunkan angket yang diadopsi dari Survei Kesehatan Reproduksi Remaja Indonesia (SKRRI) tahun 2007 dan dari jurnal BMC Public Health yang telah dilakukan ujicoba terlebih dahulu. Data dalam penelitian ini berbentuk campuran sehingga analisa data multivariate dalam penelitian ini menggunakan analisis jalur/path analysis dengan program PLS. Taraf signifikasi dilihat dari uji t dan nantinya dibandingkan dengan $t$ tabel. Dikatakan signifikan jika t hitung $>1,96$ (Ghozali, 2011 dan Yamin, 2011).

\section{HASIL}

Sebagian besar responden berjenis kelamin perempuan (51.7\%) dengan usia masuk pada remaja awal (59.4\%). Jenis tempat tinggal responden sebagian besar ikut orang tua dan kost, seluruh responden pernah mengakses informasi baik kesehatan, seksualitas maupun pornografi. Pada variabel sikap diperoleh baik sikap responden terhadap seksualitas, sikap masyarakat dan orang tua sebagian besar masuk kategori permisif $(61.9 \%)$, dan hanya sikap teman yang sebagian besar masuk kategori tidak permisif (Tabel 1).

Pengetahuan responden mengenai kesehtan reproduksi sebagian besar masuk kategori kurang (56.4\%) dan nilai virginatas responden masuk kategori baik (75\%). 
M Ulfah | Faktor-faktor yang Mempengaruhi Perilaku Seksual Pranikah pada Remaja SMP dan SMA di Wilayah Eks-Kota Administratip Cilacap

aktivitas perilaku seksual diurutkan dari yang paling banyak diakui telah dilakukan responden adalah cium pipi (50.7\%), berpelukan (49.0\%), berciuman melibatkan lidah (28.9), masturbasi/onani (23.2\%), necking (15.1\%), meraba alat kelamin $(13.8 \%)$, oral seks $(10.1 \%)$, intercourse $(8.2 \%)$, menempel alat kelamin $(6.5 \%)$, anal seks (4.9\%) (Tabel 1).

Hasil analysis yang disajikan pada gambar 1 terlihat bahwa variabel dominan secara berurutan yaitu nilai virginitas dengan nilai T- statistik 2.5954 yang berarti bahwa nilai virginitas berpengaruh terhadap perilaku seksual pranikah dengan nilai koefisien 0,0760 (7.6\%). Akses media (kesehatan, pornografi, dan seksualitas) dengan nilai Tstatistik 2.5954 yang berarti bahwa nilai virginitas berpengaruh terhadap perilaku seksual pranikah dengan nilai koefisien $0.1500(15 \%)$.

Peran guru terhadap kesehatan reproduksi dan pacaran yang sehat dengan dengan nilai T- statistik 4.8779 berarti bahwa peran guru berpengaruh terhadap perilaku seksual pranikah dengan nilai koefisien 0.1860 (18.6\%). Sikap terhadap seksualitas dengan nilai T- statistik 2.5468 berarti bahwa nilai virginitas berpengaruh terhadap perilaku seksual pranikah dengan nilai koefisien 0.1600 (16\%). Pengetahuan tentang kesehatan reproduksi dengan nilai T- statistik -2.7593 berarti bahwa nilai virginitas berpengaruh terhadap perilaku seksual pranikah dengan nilai koefisien $-0,2330$ (23.3\%)

Hasil analisis $\mathrm{R}$ square diperoleh nilai sebesar 0.336 berarti $36,6 \%$ perilaku seksual remaja SMP SMA di Kabupaten Cilacap dipengaruhi oleh nilai virginitas, akses media (pornografi dan seksualitas) peran guru dan sikap individu terhadap seksualitas, sedangkan $63,4 \%$ perilaku seksual remaja dipengaruhi factor lain yang tidak diteliti.

\section{PEMBAHASAN}

Dalam penelitian ini, nilai virginitas berpengaruh $7.6 \%$ terhadap perilaku sesual pranikah. Menurut Berck, El (2012), bahwa masa remaja adalah masa penting dalam pembentukan nilai. Remaja berusaha melepaskan diri dari orang tua untuk menemukan identitas dirinya, remaja bermaksud mengembangkan nilai-nilai baru dalam rangka mencari jalannya sendiri menuju kepribadian yang matang.

Faktor lingkungan yang berpengaruh terhadap perkembangan nilai, moral, dan sikap individu mencakup aspek psikologis, sosial, budaya, dan fisik kebendaan, baik yang terdapat dalam lingkungan keluarga, sekolah, maupun masyarakat. Kondisi psikologis, pola interaksi, pola kehidupan beragama, berbagai sarana rekreasi yang tersedia dalam lingkungan keluarga, sekolah, dan masyarakat akan mempengaruhi perkembangan nilai, moral, dan sikap individu (Elmubarok, 2008).

Akses media $15 \%$ berpengaruh langsung terhadap perilaku seksual pranikah. Tingginya dorongan media yang menyebabkan munculnya rasa ingin tahu para remaja. Andriani, dkk (2016), dalam penelitianya juga menemukan adanya hubungan antara akses media informasi dengan perilaku seksual. 
M Ulfah | Faktor-faktor yang Mempengaruhi Perilaku Seksual Pranikah pada Remaja SMP dan SMA di Wilayah Eks-Kota Administratip Cilacap

Tabel 1. Karakteristik Responden dan Variabel Penelitian $(n=596)$

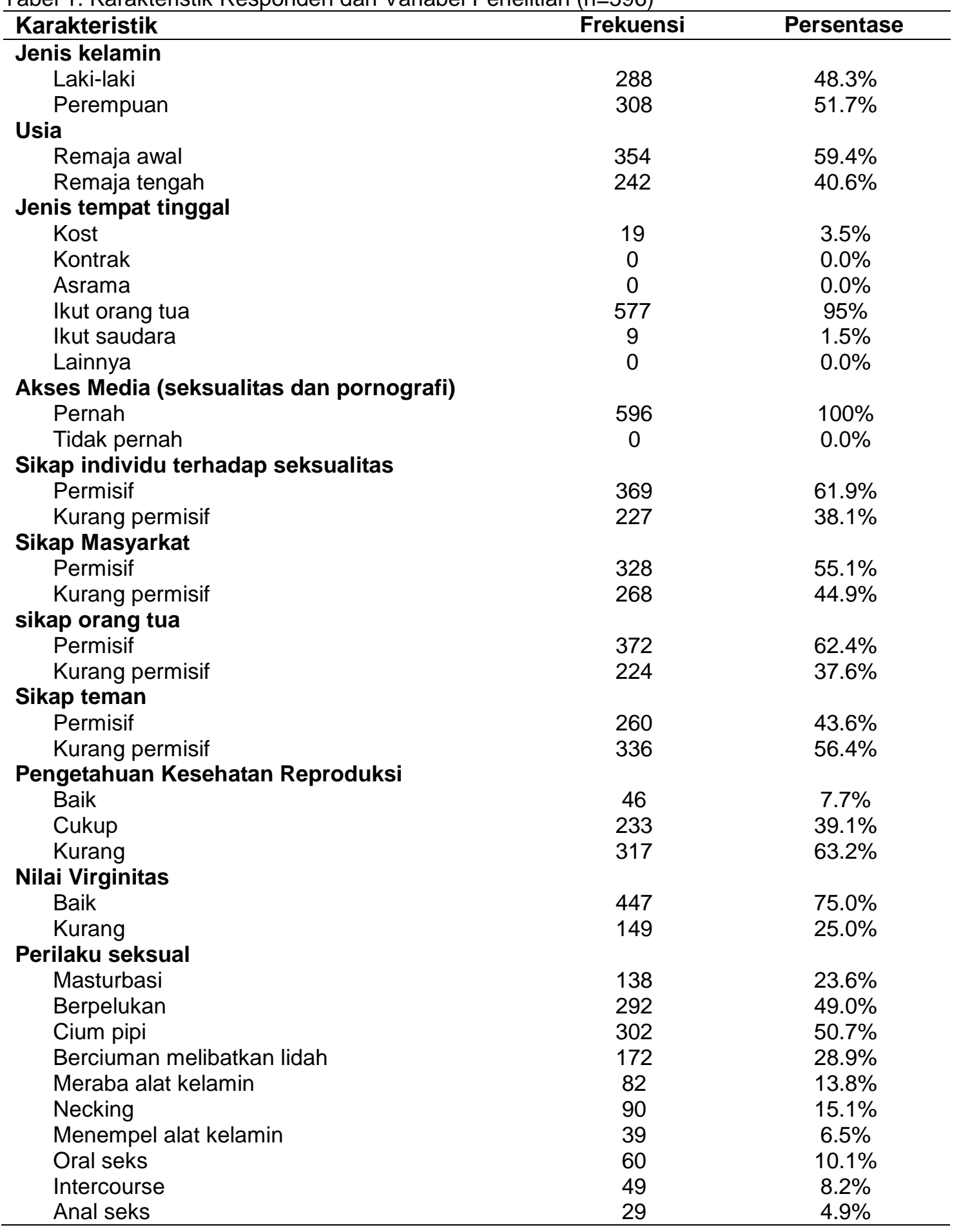

Peran guru terhadap kesehatan reproduksi dan pacaran yang sehat mempengaruhi $18,6 \%$ terhadap perilaku seksual pranikah. Hal ini sejalan dengan Foucault, M. (2010) dimana remaja yang berada pada masa sekolah sangat dipengaruhi oleh pendidik. Pendidik (guru) seharusya tidak hanya efektif dalam kegiatan belajar mengajar di kelas saja, terlebih pada pribadinya "modelingnya" baik pada peserta didik maupun kepada seluruh anggota komunitas sekolah, 


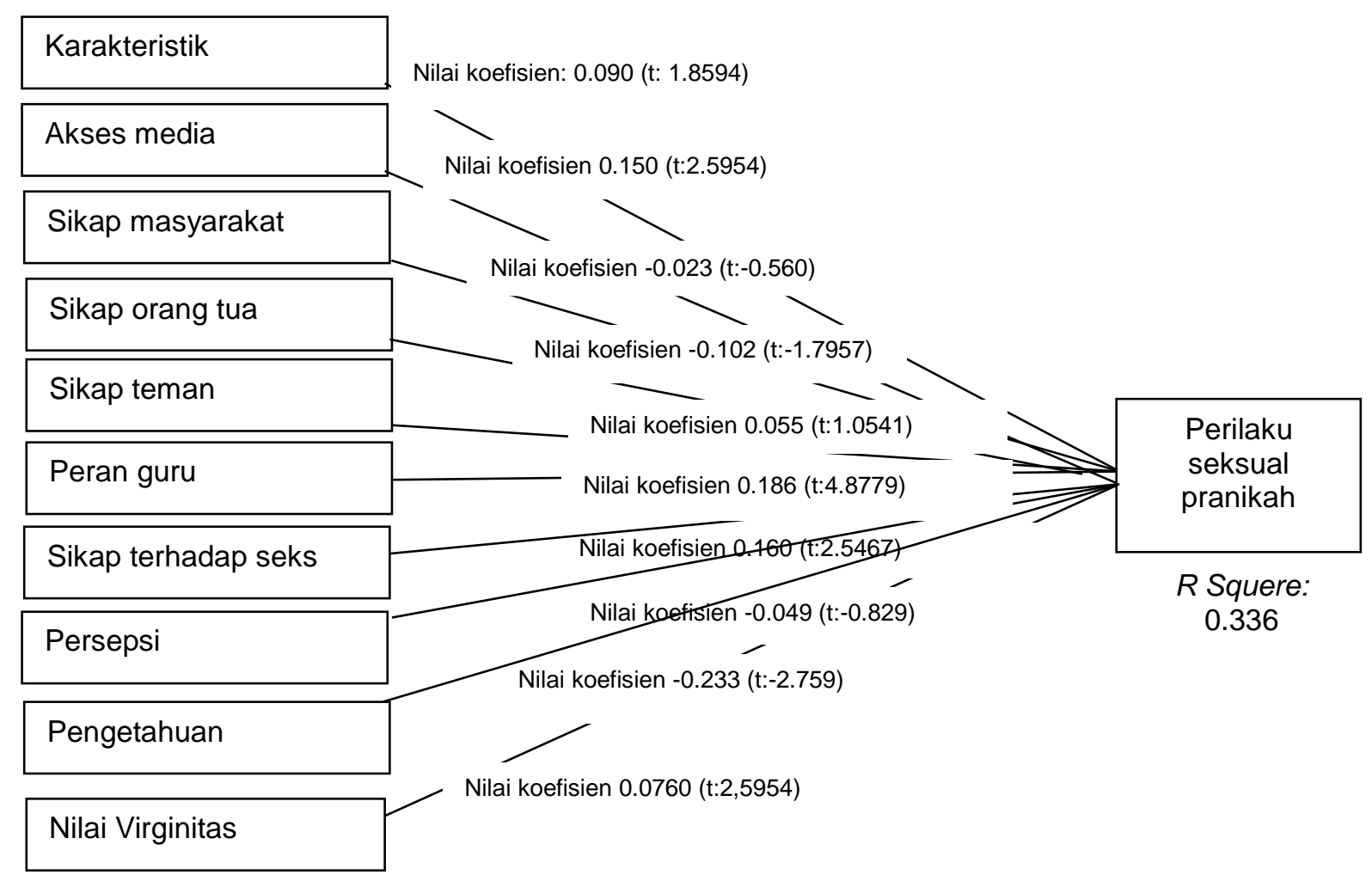

Gambar 1. Diagram Jalur Factor-faktor yang Berpengaruh Terhadap Perilaku Seksual Pranikah

karena komunitas di sekolah sangat berpengaruh terhadap perkembangan remaja, karena sekolah adalah lembaga pendidikan yang mengajarkan nilai-nilai dan norma yang berlaku di masyarakat.

Sikap terhadap seksualitas berpengaruh $16 \%$ terhadap perilaku seksual pranikah. Hal ini sesuai dengan pendapat Ratna, (2010) yang menyatakan bahwa faktor lain yang mendorong individu untuk melakukan hubungan seksual pranikah adalah kontrol diri yang lemah, individu dengan kontrol yang lemah lebih dapat dipengaruhi orang oleh orang lain maupun dari lingkungannya

Pengetahuan tentang kesehatan reproduksi $23 \%$ berpengaruh langsung terhadap perilaku seksual pranikah. Hal ini sejalan dengan Glanz (2010) bahwa factor-faktor yang mempengaruhi perilaku adalah salah satunya factor kognitif, remaja yang memiliki pengalaman secara benar dan proposional tentang kesehatan reproduksi cenderung memahami resiko perilaku serta alternatif cara yang tepat digunakan untuk menyalurkan dorongan seksual secara sehat dan bertanggung jawab. Sejalan dengan penelitian Andriani, dkk (2016) bahwa siswa yang memiliki pengetahuan cukup, 62.3\% memiliki perilaku seksual berisiko, sedangkan siswa yang memiliki pengetahuan kurang, perilaku seksual berisiko meningkat menjadi $91.9 \%$.

\section{KESIMPULAN DAN SARAN}

Hasil penelitian menunjukkan $36.6 \%$ perilaku seksual pranikah pada remaja SMP dan SMA di Kabupaten Cilacap dipengaruhi oleh akses media, peran guru, persepsi, pengetahuan dan nilai virginitas. Diharapkan 
pada remaja SMP SMA untuk lebih meningkatkan pengetahuan remaja berkaitan dengan kesehatan reproduksi dan menghilangkan budaya tabu terhadap kesehatan reproduksi, menghindari akses media yang berhubungan dengan pornografi serta mampu melakukan proteksi terhadap perilaku seksual pranikah melalui kegiatan yang positif.

\section{DAFTAR PUSTAKA}

Andriani, H., Yasnani., A. (2016). Hubungan pengetahuan, akses media informasi, dan peran keluarga terhadap perilaku seksual pada siswa SMK N Kendari Jurnal Ilmiah Mahasiswa Kesehatan Masyarakat, 1(3):1-11

Tim SDKI. (2018). Survei Demografi dan Kesehatan Reproduksi 2017 Kesehatan Reproduksi Remaja. Jakarta: BKKBN Indonesia

Berck, E.L. (2012). Dari Prenatal Sampai Remaja. Jakarta: Pustaka Pelajar.

Dhion, $M$ et al. (2011) Tingkat Pengetahuan dan Sikap Remaja Usia 12-17 Tahun di RW V Kelurahan Tambakreja, Kecamatan Cilacap Selatan, Kabupaten Cilacap Terhadap Seks Bebas. Jogjakarta: Fakultas Kedokteran UGM (Laporan Praktik profesi).

Elmubarok, Z. (2008). Membumikan Pendidikan Nilai. Bandung: Alfabeta

Fanchaurt, M. (2010). Agama dan Seksualitas. Jakarta: Jalasutra.

Ghozali, I. (2011). Structural Equation Modeling Edisi 3 Metode Alternatif dengan Partial Least Square (PLS). Semarang: Badan Penerbit Universitas Indonesia.

Glanz et al. (2010) Social Cognitive Theory. University of Twente. http://www.utwente.nl/cw/theorieenoverz icht/Theory\%20clusters/Health\%20Com munication/Social cognitive theory.doc/

Notoatmodjo, S. (2010). Promosi Kesehatan Teori dan Aplikasi. Jakarta: Rineka Cipta.

Ratna, W. (2010). Sosiologi dan Antropologi Kesehatan Dalam Perspektif IImu Keperawatan. Jogjakarta: Pustaka Rihama.

Sugiyono. (2010). Statistika untuk Penelitian. Bandung: Alfabeta.
Suharsimi, A. (2010). Prosedur Penelitian Suatu Pendekatan Praktik. Yogyakarta: Rineka Cipta.

Wisesa, $S$ et al. (2011). Hubungan Antara Tingkat Pengetahuan Kesehatan Reproduksi dengan Perilaku Seksual Remaja di SMU Muhammadiyah Cilacap. Jogjakarta: Fakultas Kedokteran UGM (Laporan Praktik profesi).

Yamin S, Kurniawan H. (2011). Generasi Baru Mengolah Data Penelitian dengan Partial Least Square Path Modeling. Jakarta: Salemba Infotek 